\title{
A redescription and synonymy of North African mygalomorph Iberesia barbara (Lucas, 1846), comb.n. (Aranei: Nemesiidae)
}

\author{
Переописание и синонимия североафриканского \\ мигаломорфного паука Iberesia barbara (Lucas, 1846), comb.n. \\ (Aranei: Nemesiidae)
}

\author{
Sergei L. Zonstein

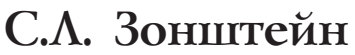

Department of Zoology, Steinhardt Museum of Natural History, Tel-Aviv University, 69978 Tel-Aviv, Israel. Email: znn@post.tau.ac.il

KEY WORDS: Araneae, taxonomy, spiders, new combination, new synonymy, Algeria, Morocco.

КЛЮЧЕВЫЕ СЛОВА: Araneae, таксономия, пауки, новая комбинация, новая синонимия, Алжир, Марокко.

ABSTRACT. North African Nemesia barbara Lucas, 1846 is redescribed from types and conspecific material and transferred to Iberesia Decae et Cardoso, 2006. It differs from other Iberesia species in possessing a noticeably shorter and less tapering embolus and wider bases of the short spermathecae. Nemesia vittipes Simon, 1911 is recognized here to be a junior synonym of Mygale barbara Lucas, 1846. New data on the distribution of I. barbara are provided and its relationships are briefly considered.

РЕЗЮМЕ. Североафриканский Nemesia barbara Lucas, 1846 переописывается по типовому и конспецифичному материалу и перемещается в род Iberesia Decae et Cardoso, 2006. От других видов рода Iberesia он отличается значительно более коротким и менее суживающимся к вершине эмболюсом, и широкими основаниями укороченных сперматек. Nemesia vittipes Simon, 1911 признан младшим синонимом Mygale barbara Lucas, 1846. Приводятся новые данные по распространению $I$. barbara и вкратце рассматриваются его родственные связи.

\section{Introduction}

Nemesia barbara Lucas, 1846, whose redescription is provided below, has a long but uneventful study history. Described originally by Lucas [1846] as a member of Mygale Walckenaer, 1802 (a recognized homonym of Mygale Cuvier, 1800; Mammalia), it was later transferred by Simon [1892] to the widespread Circum-Mediterranean Nemesia Audouin, 1826. Since then, the species, although described minutely, has never subjected to any taxonomical study. All presented data have been based only upon those of the original description published 170 years ago. Because Nemesia currently embraces about 60 species, described mostly in 1873-2011 [WSC, 2016], the above-noted data should thus be regarded as deficient.

The present study is based on the examination of numerous nemesiid specimens collected in North Africa and deposited in the Simon's collection of the Muséum national d'Histoire naturelle, Paris. This examination showed that Mygale barbara actually belongs to the genus Iberesia Decae et Cardoso, 2006; and this name is a senior synonym of Nemesia vittipes Simon, 1911 described from Morocco.

\section{Material and methods}

All specimens of Iberesia barbara, including the type series of Mygale barbara and Nemesia vittipes used for study, were borrowed from the spider collection of the Muséum national d'Histoire naturelle, Paris, France (MNHN).

The types and other specimens of I. brauni (L. Koch, 1882) deposited in the Natural History Museum, London, UK, as well as those of I. castillana (Frade et Bacelar, 1931) and I. machadoi Decae et Cardoso, 2006 kept in MNHN, were examined while visiting those museums in 2010 and 2012, respectively.

Photographs were taken using a Zeiss Discovery V20 stereomicroscope with a Canon PowerShot G9 camera (structures), and a Canon EOS-500D camera with Canon EF-100mm f2.8 USM macro lens (totals), and prepared using the Helicon Focus 6.3.2 Pro (http:// www.heliconsoft.com) and CombineZP (http:// hadleyweb.pwp.blueyonder.co.uk/) software. Illustration of the spermathecae was made after its maceration in $20 \%$ potassium hydroxide aqueous solution and in $85 \%$ lactic acid. A background map was obtained from the public internet source http://www.maps-forfree.com.

Measurements were made to an accuracy of 0.01 $\mathrm{mm}$. Lengths of leg and palp segments were measured 

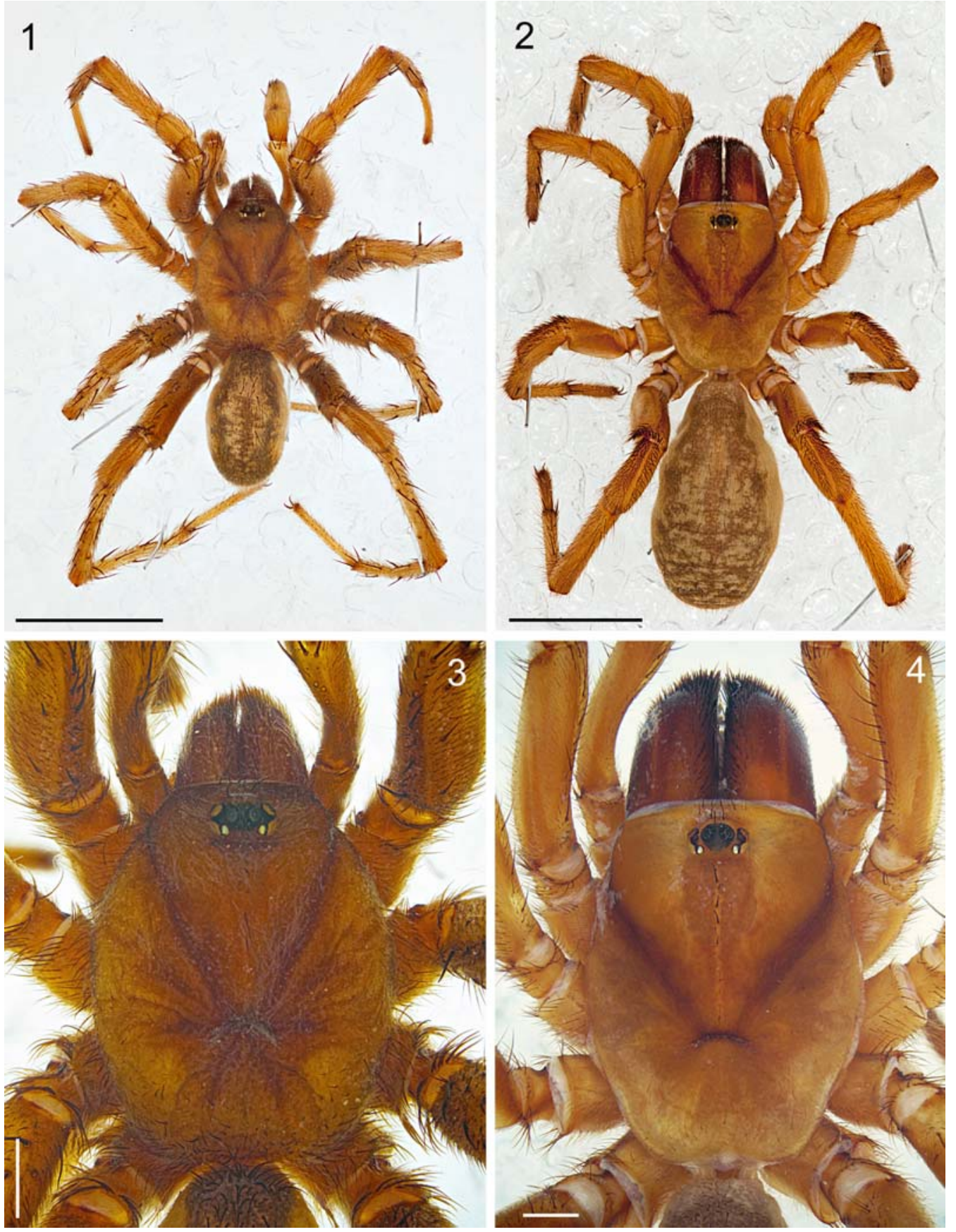

Figs. 1-4. Iberesia barbara, male MNHN 6163 /AR $4486(1,3)$ and female MNHN 6143 / AR4481 (2, 4): 1, 2 -dorsal view; 3, 4 prosoma dorsally. Scale bars for Figs $1-2-5.0 \mathrm{~mm}$, for $3-4-1.0 \mathrm{~mm}$.

Рис. 1-4. Iberesia barbara, самец MNHN 6163 /AR $4486(1,3)$ и самка MNHN 6143 / AR4481 $(2,4): 1$ - общий вид сверху; 2 просома сверху. Масштаб для рис. 1-2 - 5,0 мм, для 3-4-1,0 мм.

on the dorsal side, from the midpoint of the anterior margin to the midpoint of the posterior margin; they are listed as: total (femur + patella + tibia + metatarsus + tarsus). All measurements are given in millimetres (for eyes they are also given in parentheses, when include or count tapetum).
Abbreviations used in text are: ALE — anterior lateral eyes; AME - anterior median eyes; d, dorsal; PLE - posterior lateral eyes; PLS — posterior lateral spinnerets; PME — median lateral eyes; PMS — posterior median spinnerets; $\mathrm{p}$ - prolateral; $\mathrm{pd}$ - prodorsal; pv - proventral; $r$ - retrolateral; rd - retrodorsal; rv - retroventral; v - ventral. 


\section{Taxonomy}

Family NEMESIIDAE Simon, 1889

Genus Iberesia Decae et Cardoso, 2006

Iberesia Decae, Cardoso, 2006: 4.

TYPE SPECIES. Iberesia machadoi Decae et Cardoso, 2006, by original designation.

NOTES. Iberesia was established and separated from the related genus Nemesia on the basis of possessing the following characters: a complete absence of posterior median spinnerets, a short row of 3-6 spiky cuspules along the proximal edge of the maxillae, and the presence of a retrolateral megaspine on the female tibia III (see Decae \& Cardoso [2006]).

COMPOSITION. Iberesia barbara (Lucas, 1846) (Algeria, Morocco), I. brauni (L. Koch, 1882) (Balearic Isles); I. castillana (Frade et Bacelar, 1931) (mainland Spain) and I. machadoi Decae et Cardoso, 2006 (Portugal).

DISTRIBUTION. Western Mediterranean (Fig. 30).

Iberesia barbara (Lucas, 1846), comb.n. Figs 1-17.

Mygale barbara Lucas, 1846: 89, pl. 1, fig. 1 (lectotype $\sigma^{7}$, MNHN, examined).

Nemesia barbara: Simon, 1892: 113.

Nemesia vittipes Simon, 1911: 414 (Holotype $\sigma^{7}, \mathrm{MNHN}$ examined). Syn.n.

MATERIAL. Lectotype $\sigma^{7}$ of Mygale barbara (designated here) - ALGERIA [without further details; but Oran, Alger and El Kala ("Lacalle") are mentioned in the original description]: 1840-1842, H. Lucas (MNHN AR 5060). Paralectotypes (designated here): 4 $\sigma^{7} \sigma^{7}$ with the same collecting data $(\mathrm{MNHN})$. Other material collected from Algeria: Tlemsen, E. Simon [no date] - $3 \sigma^{7} \sigma^{7}$ (MNHN 4115 / AR 4429); Oran, 1883, E. Simon - 3 ๙ $^{7}, 2$ 우 (MNHN 6163 / AR 4486); Le Kreider (= El Kreither), May 1883, E. Simon - 8 + + (MNHN 6143 / AR 4481); Daya, L. Bedel [no date] - $4 \sigma^{7} \sigma^{7}$ (MNHN 1073 / AR 4478). Holotype $\sigma^{7}$ of Nemesia vittipes MOROCCO: "Aïn Spa" = Oued Cifrou 8 km N Aïn Sfa, $750 \mathrm{~m}$, 26-28.11.1909, R. Jeannel (MNHN 15464 / AR 4444).

DIAGNOSIS. In the shape of the male palpal tibia and bulb I. barbara resembles I. brauni. In males of both species the palpal tibia shorter and also more thick and swollen than that in I. castillana, and longer and thinner than in I. machadoi. The bulb of I. barbara is also similar to that of $I$. brauni. However, males of $I$. barbara differ from those of I. brauni in a shorter and noticeably less tapering embolus, as well as in the shape of the subapical embolic teeth (very gently elevated and almost indistinct in I. barbara, but acute and well-visible in I. brauni (cf. Figs 9-12 and 24-25). Females of I. barbara and I. brauni also share a similar shape of bipartite spermathecae which differ well from tripartite spermathecae in I. machadoi (see Fig. 29; no conspecific female has not yet been described for $I$. castillana). Broad bases of the spermathecae in I. barbara are almost as wide as their heads, whereas in $I$. brauni they are noticeably narrower (cf. Figs 15 and 28).
MALE (lectotype MNHN AR 5060) (Figs 1, 18). Body length 11.75 .

Color in alcohol: prosoma intensive yellowish-brown with more dark chelicerae, palpal and leg femora, clypeus, cephalic region and radial ridges on carapace; eye tubercle dark brown with blackish areas surrounding eyes; ventral part of prosoma, palps, legs and spinnerets dark yellow; abdomen greyish-yelow, dorsally with darker brownish pattern consisting of <-shaped spot anteriorly and narrow median stripe behind, interrupted and crossed posteriorly with several transverse fasciae.

Prosoma as shown in Figs 3 and 7. Carapace 5.03 long, 4.38 wide. Eye tubercle as shown in Fig. 5. Eye diameters and interspaces: AME 0.17(0.25), ALE 0.25, PLE 0.25, PME: 0.12, AME-AME 0.20(0.12), ALEAME 0.13(0.09), ALE-PLE 0.08, PLE-PME 0.05, PME-PME 0.46. Chelicerae: furrow with 6 promarginal teeth, one medium and 10-12 tiny mesobasal denticles; rastellum consists of 6 large cone teeth and few smaller stout spines in front of cheliceral fang base. Labium 0.51 long, 0.80 wide. Sternum 2.65 long, 2.10 wide. Sternal sigilla small submarginal. Maxillae with 3 small shaft cuspules confined to maxillary heel.

Tibia and metatarsus I as shown on Fig. 14. Tarsi IIV elongate and slightly curved altough not pseudosegmented. Palp and leg length. Palp: $6.63(2.37+1.24+$ $2.04+0.98)$. Leg I: $16.34(4.46+2.22+3.46+3.27+$ 2.93). Leg II: $16.28(4.30+2.12+3.43+3.61+2.82)$. Leg III: $16.89(4.05+2.07+3.24+4.58+2.95)$. Leg IV: $22.49(5.32+2.37+5.52+6.11+3.17)$. Spines: tarsi I-II with 5-6 small ventral spines. Palp: femur d11-1-2, dp1; patella p1; tibia d5(6) apical, p1; tarsus d17-20. Leg I: femur d1-1-1-1-1-1-2, pd0-1-1, rd1-11; patella p1-1; tibia p1-1-1, r1-0-1, pv1-1-M, rv1-1-1; metatarsus pd0-1-1-0, rd0-1-1, p1-1-1, r1-1-1, v1-1-2. Leg II: femur d1-1-1-1-1-1-2, pd1-1-1, rd1-1-1; patella p1-1; tibia p1-1-1, v2-2-2; metatarsus pd0-1-1-0, rd00-1, p1-1-1, r1(0)-1-1, v2-1-2. Leg III: femur d1-1-11-1-2, pd1-1-1, rd1-1-1; patella p1-1, r1; tibia d2-1-20, p1-1-1-0, r1-1-1, v2-2-3; metatarsus d1-1-1-1, p1-11-1, r1-1-1, v2-2-3; tarsus p1. Leg IV: femur d1-1-1-11-1-1-2, pd1-1-1, rd1-1-1; patella p1, r1; tibia d2-1-11-1, p1-1-1-1-1, r1-1-1-1; v2-2-3; metatarsus d1-1-10-1, p1-1-1-1, r1-1-1-1, v2-1-2-3; tarsus d1, p0-1-1(0). Scopula: entire and distal on metatarsi I-II; divided by spine row on tarsi I-II; absent on tarsi III-IV. Trichobothria: 2 rows of $9-11$ per row on tibiae, $12-13$ on metatarsi, $10-12$ on tarsi, 8-9 on cymbium. Paired tarsal claws with 5-6 teeth on inner margin and with 78 teeth on outer margin. Unpaired tarsal claw small steeply curved.

Copulative organs. Palpal tibia swollen (Figs 9, 13). Bulb with moderately long tapered and curved embolus with two tiny hardly visible subapical teeth, as in Figs 10-12.

Spinnerets as shown on Fig. 16. PLS: maximal diameter 0.53 ; length of basal, medial and apical segments $0.64,0.16,0.08$; total length 1.02 ; apical segment domed. 

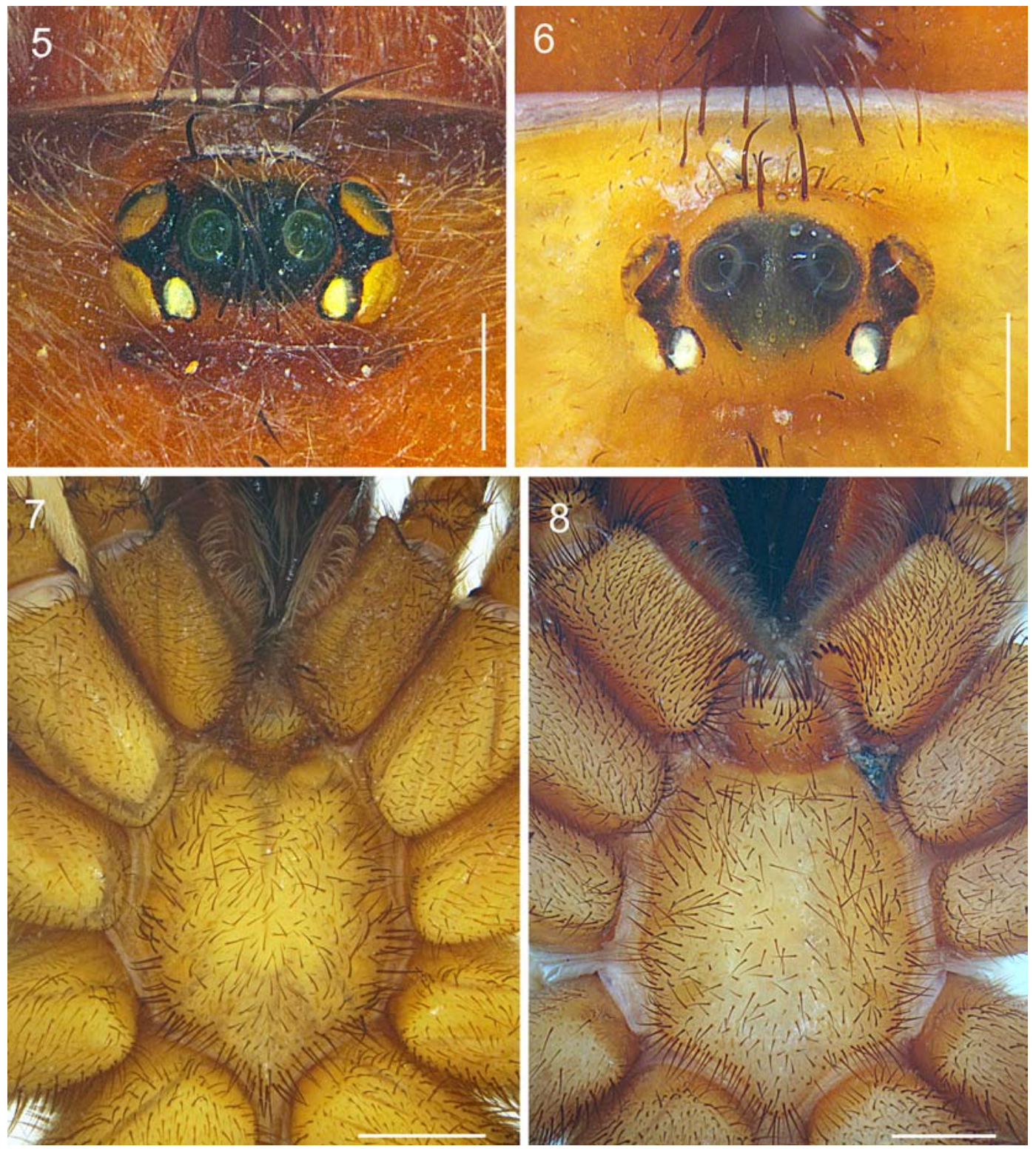

Figs. 5-8. Iberesia barbara, male MNHN 6163 /AR $4486(5,7)$ and female MNHN 6143 / AR4481 $(6,8): 5,6$ - eye tubercle dorsally; 7, 8 - prosoma ventrally. Scale bars for Figs $5-6-0.5 \mathrm{~mm}$, for 7 and $8-1.0 \mathrm{~mm}$.

Рис. 5-8. Iberesia barbara, самец MNHN 6163 /AR 4486 (5-6) и самка MNHN 6143 / AR4481 (7, 8): 5, 6 — глазной бугорок сверху; 7, 8 - просома снизу. Масштаб для рис. 5-6-0,5 мм, для 7-8-1,0 мм.

FEMALE (MNHN 6143 / AR 4481). Body length 19.20. Color in alcohol as in male (Fig. 2).

Prosoma as shown in Figs 4, 8. Carapace 7.03 long, 5.26 wide. Eye tubercle as shown in Fig. 6. Eye diameters and interspaces: AME 0.18(0.26), ALE 0.28, PLE 0.24, PME: 0.17, AME-AME 0.24(0.16), ALE-AME 0.18(0.14), ALE-PLE 0.05, PLE-PME 0.04, PME-PME 0.55 . Chelicerae: furrow with 6 promarginal teeth and with 3-4 medium anterior and 15-17 tiny posterior mesobasal denticles; rastellum consists of 6-7 large cone teeth and 15-20 smaller stout spines. Labium 0.77 long, 1.38 wide. Sternum 3.60 long, 2.91 wide.
Sternal sigilla small submarginal. Maxillae with 3-4 cuspules along heel.

Palp and leg length. Palp: $7.96(3.53+1.83+2.28+$ 2.28). Leg I: $14.84(4.50+2.64+3.23+2.67+1.80)$. Leg II: $13.83(4.26+2.48+2.81+2.73+1.55)$. Leg III: $13.20(3.76+2.15+2.17+3.08+2.04)$. Leg IV: $20.36(5.52+3.18+4.97+4.39+2.30)$.Spines: all femora with longitudinal dorsal row of 4-5 bristles; all palellae and tarsi III-IV unarmed; tarsi I-II with 8-10 small ventral spines. Palp: tibia v2-2-3, tarsus $1-1-2-$ 2-2. Leg I: tibia v1-2(1)-2; metatarsus v1-1-2(1). Leg II: tibia v2(1)-1-2; metatarsus v2-1-3. Leg III: 

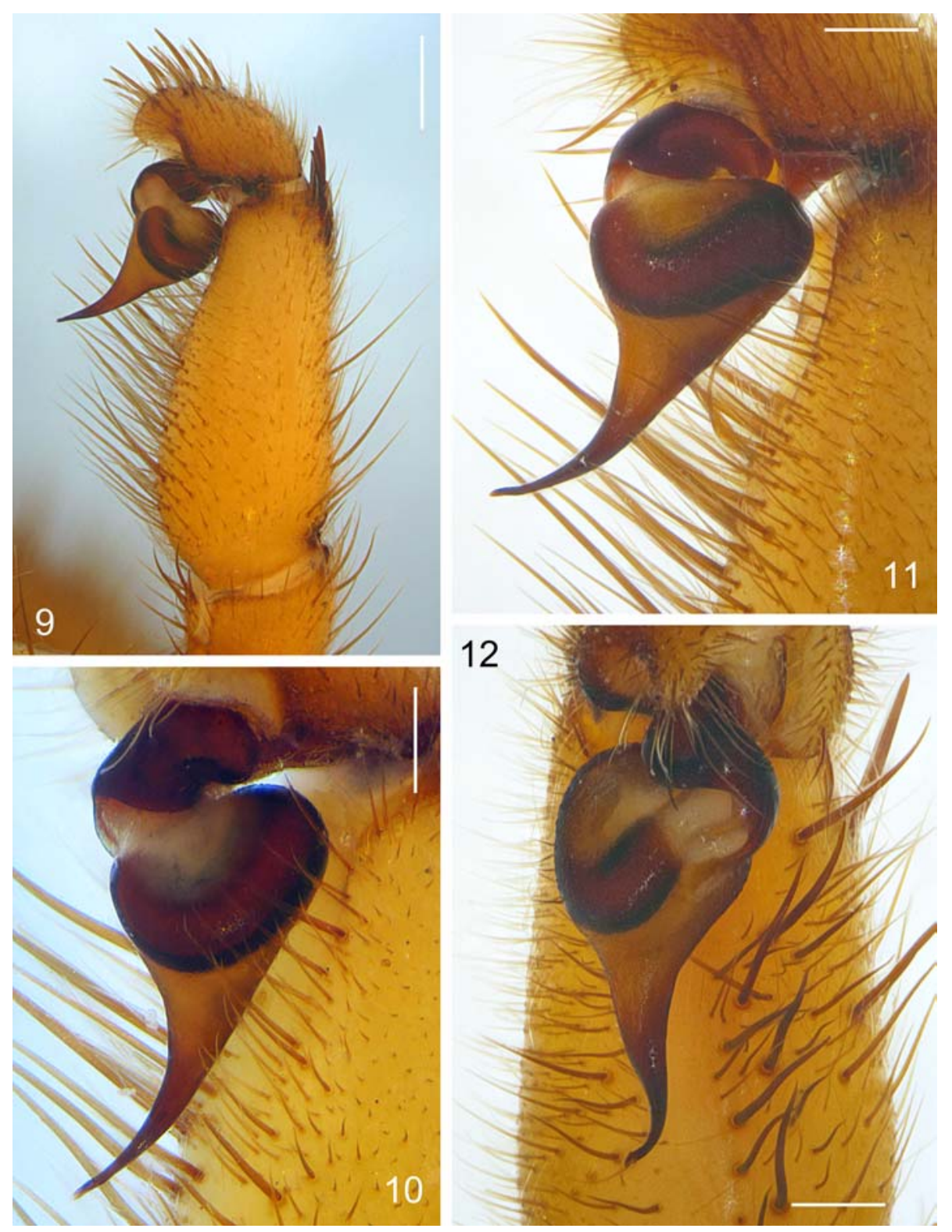

Figs. 9-12. Iberesia barbara, lectotype male MNHN AR 5060 (9-10) and male MNHN 6163 /AR 4486 (11-12): 9 - distal segments of pedipalp, showing bulb and embolus, retrolateraly; 10,11 - bulb and embolus close up, retrolateraly; 8 - same, ventrally. Scale bars for Fig. $9-0.5 \mathrm{~mm}$, for $10-12-0.25 \mathrm{~mm}$.

Pис. 9-12. Iberesia barbara, самец лектотип MNHN AR 5060 (9-10) и самец MNHN 6163 /AR 4486 (11-12): 9 — дистальные сегменты педипальпы, бульбус и эмболюс сбоку (снаружи); 10, 11 - бульбус и эмболюс сбоку (снаружи) при большем увеличении; $12-$ то же, снизу. Масштаб для рис. $9-0,5$ мм, для 10-12-0,25 мм.

tibia v2-2-2; metatarsus v2-2-3. Leg IV: tibia v22(1)-3(2); metatarsus v2-3(1)-3(2). Scopula: distal on metatarsi I-II, divided by spines on tarsi I-II and palpal tarsus; absent on tarsi III-IV. Trichobothria: 2 rows of 9-11 per row on tibiae, 11-14 on metatarsi, 12-14 on tarsi I-IV, 12-13 on palpal tarsus. Paired tarsal claws: with 6-8 teeth per row on tarsi I-III and with 2 3 teeth per row on tarsus IV. Unpaired tarsal claw small and steeply curved. Palpal claw with 2-3 promarginal teeth.
Copulative organs. Spermathecae entire, short and mushroom-like, and separated approximately by 4 their maximal width from each other, as shown in Fig. 15.

Spinnerets (Fig. 17). PLS: maximal diameter 0.72; length of basal, medial and apical segments 0.96, 0.29, 0.09; total length 1.34; apical segment domed.

VARIATION. Carapace length in males varies from 4.52 to 5.67 , in females from 4.89 to 7.12 . Darker dorsal pattern of the abdomen may be less distinct in the paler specimens. 


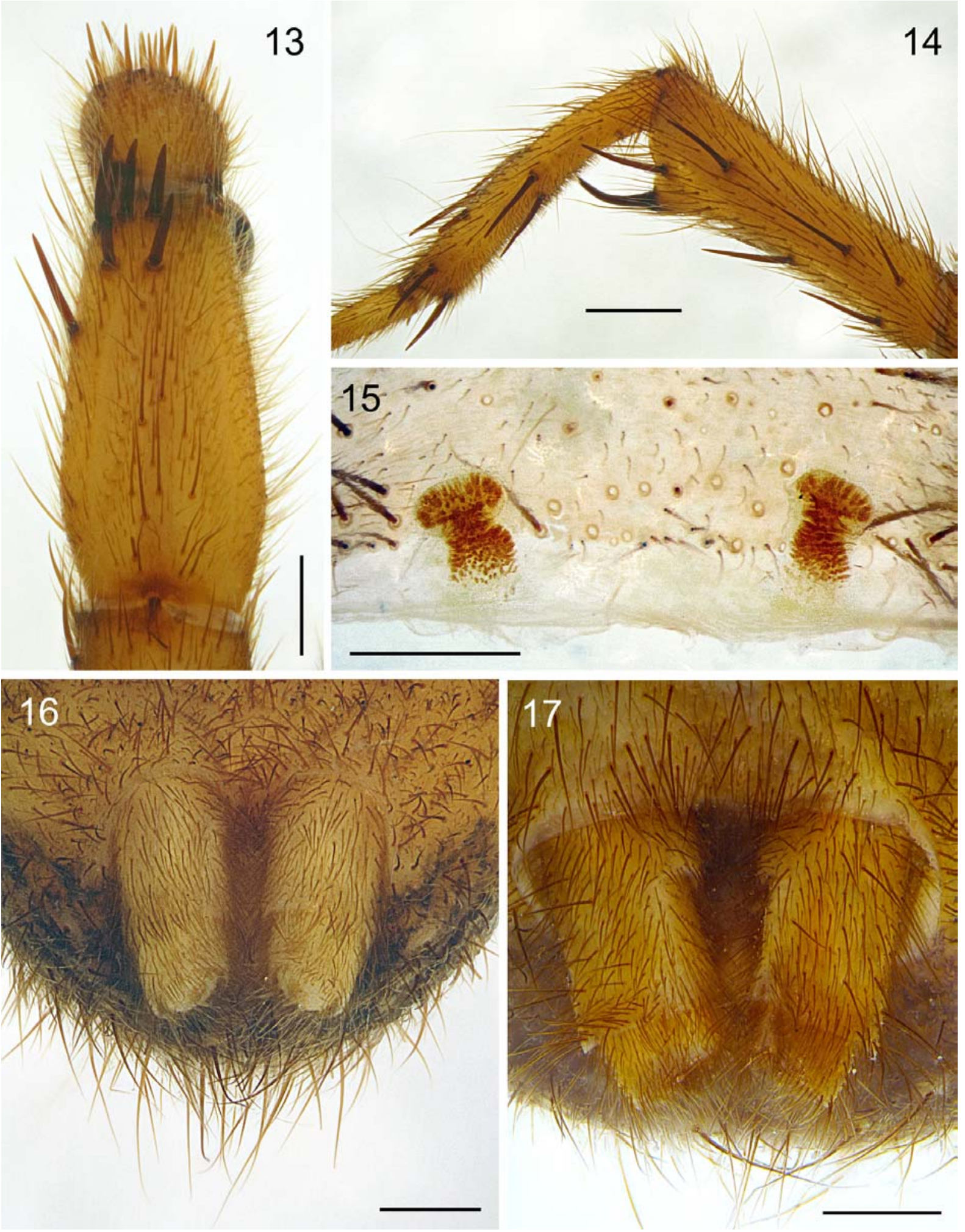

Figs. 13-17. Iberesia barbara, male MNHN 6163 /AR $4486(13-14,16)$ and female MNHN 6143 / AR4481 (15, 17): 13 - palpal tibia and cymbium, dorsally; 14 - tibia and metatarsus I retrolaterally; 15 - spermathecae dorsally; 16,17 — spinnerets ventrally. Scale bars for Figs 13, 15-17-0.5 mm, for Fig. $14-1.0 \mathrm{~mm}$

Рис. 13-17. Iberesia barbara, самец MNHN 6163 /AR $4486(13-14,16)$ и самка MNHN 6143 / AR4481 $(15,17): 13$ - голень пальпы и цимбиум, сверху; 14 - голень и предлапка I сбоку (снаружи); 15 - сперматеки сверху; 16, 17 — паутинные бородавки снизу. Масштаб для рис. $13,15-17-0,5$ мм, для $14-1,0$ мм. 

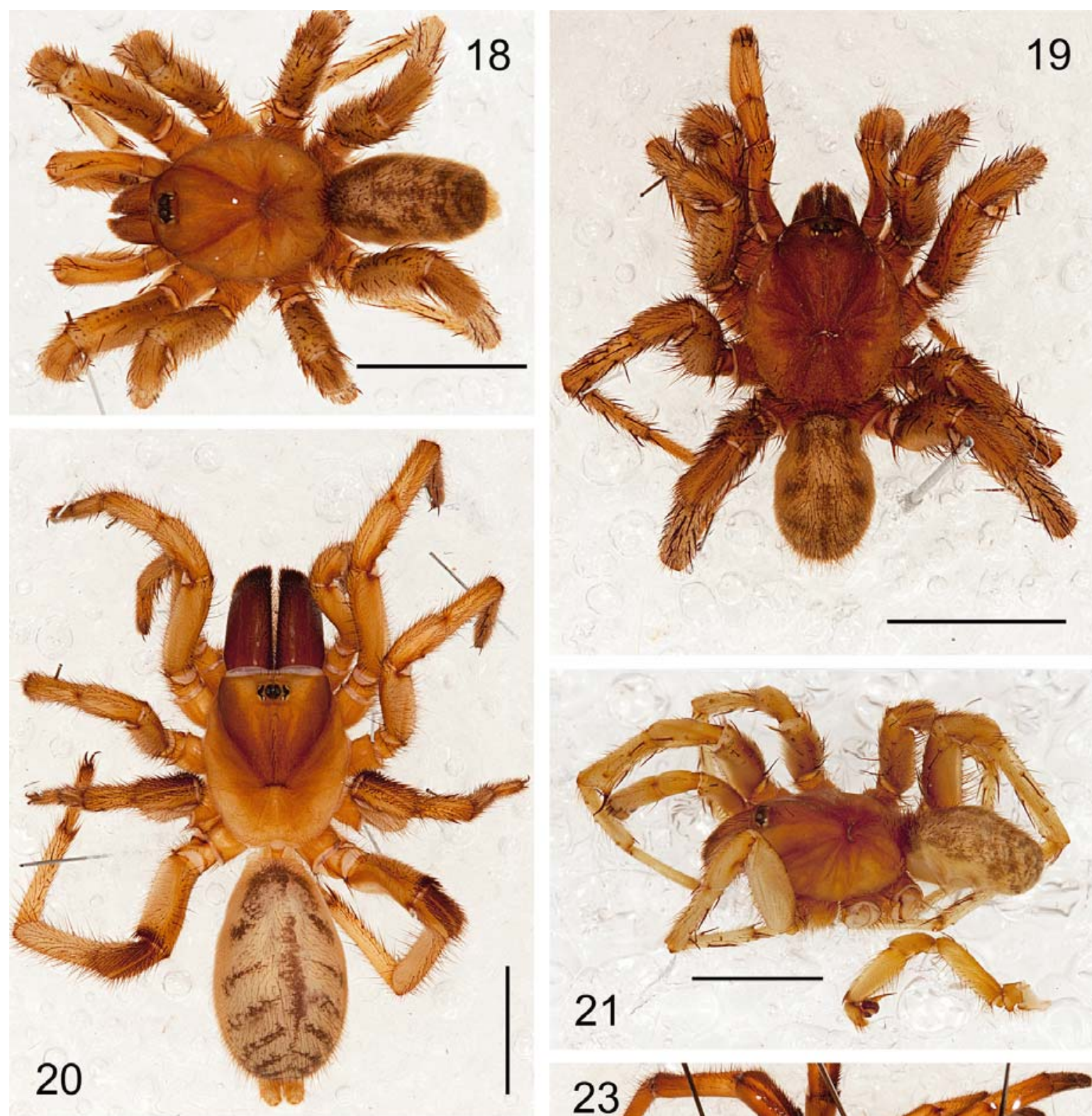

19
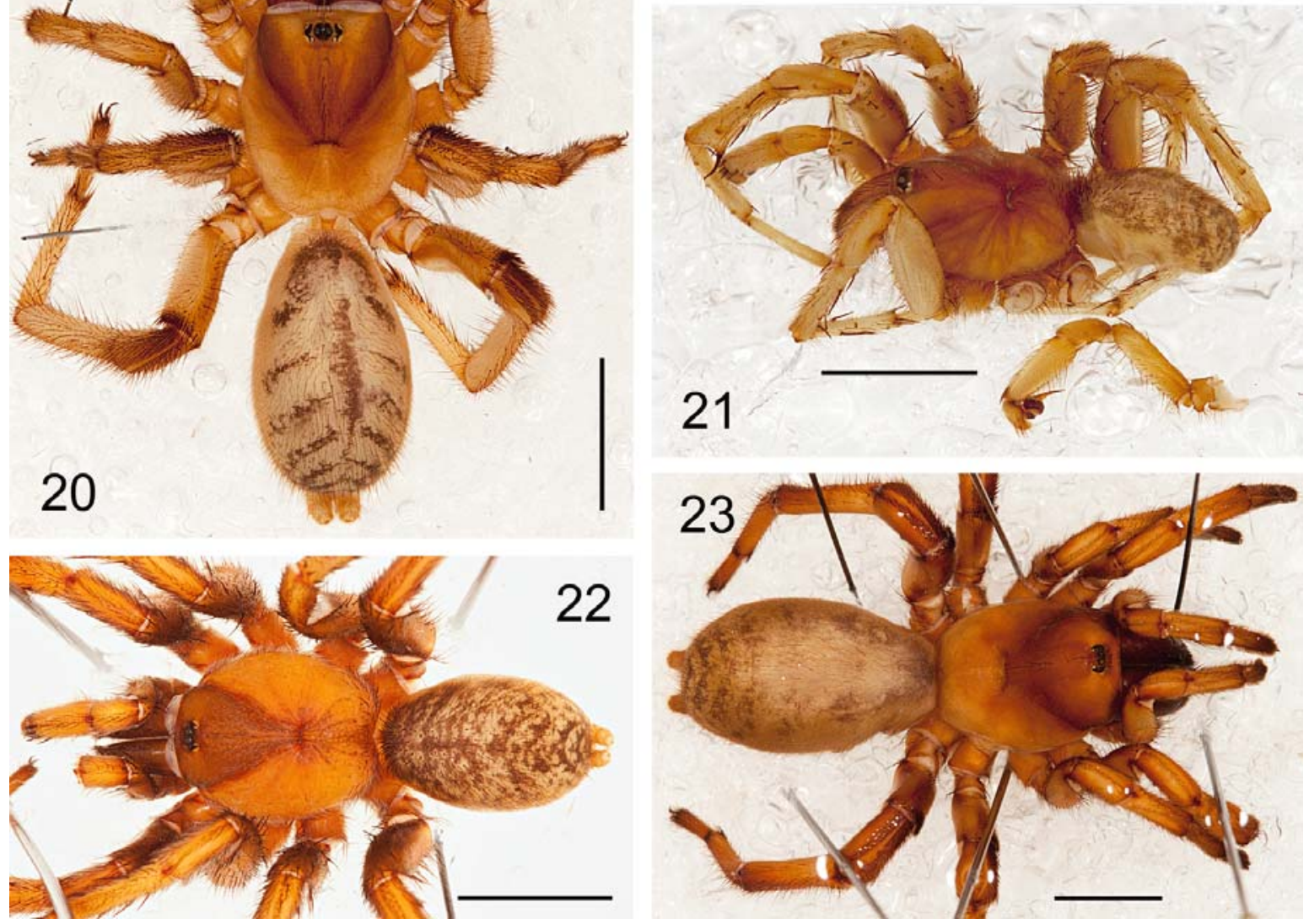

Figs. 18-23. Iberesia spp., habitus and body pattern in dorsal view: $18-I$. barbara, male lectotype MNHN AR 5060; 19, $20-I$. brauni, male and female from La Palma, Majorca (NHML); 21 - I. castillana, holotype male MNHN 6045; 22-23 — I. machadoi, male and female paratypes (MNHN). Scale bars - $5.0 \mathrm{~mm}$.

Рис. 18-23. Виды р. Iberesia, общий вид и окраска тела сверху: 18 - I. barbara, самец лектотип MNHN AR 5060; 19, $20-I$. brauni, самец и самка из Ла Пальмы, о-в Майорка (NHML); 21 - I. castillana, самец голотип MNHN 6045; 22, 23 - I. machadoi, самец и самка паратипы (MNHN). Масштаб 5,0 мм. 

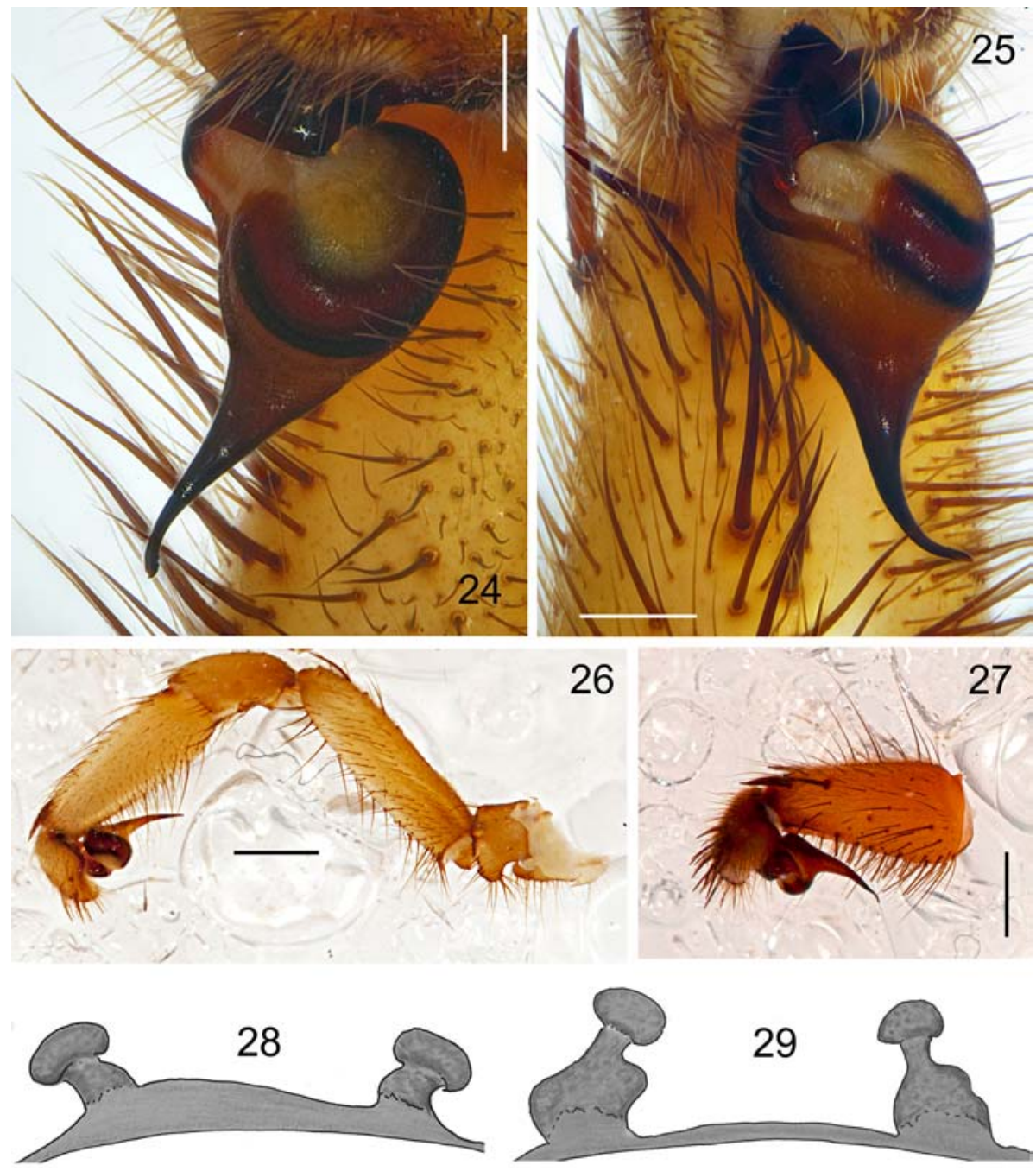

Figs. 24-29. Iberesia spp., details of male palp (24-27), and female spermathecae (from Decae, Cardoso, 2006) (28-29), retrolaterally $(24,26)$, dorsally $(25,28-29)$ and prolaterally $(27): 24-25,28-$ I. brauni; $26-$ I. castillana; $27,29-$ I. machadoi. Scale bars for Figs 24-25-0.25 mm, for $26-27-1.0 \mathrm{~mm}$.

Рис. 24-29. Виды р. Iberesia, детали пальпы самца (24-27) и сперматеки самки (по Decae, Cardoso, 2006) (28-29), сбоку снаружи $(24,26)$, сверху $(25,28-29)$ и с внутренней стороны (27): 24-25, 28 - I. brauni; 26 - I. castillana; 27,29 - I. machadoi. Масштаб для рис. $24-25-0,25$ мм, для 26-27-1,0 мм.

DISTRIBUTION. North-eastern Morocco and northern part of Algeria. For the records see Fig. 30.

ECOLOGY. Unknown.

\section{Discussion}

The studied species is thus considered to be the fourth known (and concurrently the only African) member of Iberesia. Its taxonomic position as posited here can be confirmed by the occurrence in all the examined conspecific specimens of a complete set of the features characteristic for this genus: the PMS are lost, the maxillae are provided with only a few cuspules confined to the maxillary heel, the female tibia
III is armed with a retrolateral megaspine (see Decae \& Cardoso [2006]), the embolus is curved sideward apically and bears the subapical microteeth (somewhat resembling the neck of the lute with tuners), and the spermathecae are mushroom-like. It should be noted that the occurrence of Iberesia in north-western Africa is not surprising. Indeed, it would be unusual if the taxon so widely distributed throughout the territory adjoining this region would not also have been found inside it.

Within the members of this group, I. barbara shows the closest relationships to I. brauni. Nemesia vittipes, described from a single male collected in Morocco [Simon, 1911] was in the course of its examination found to be indistinguishable in charac- 


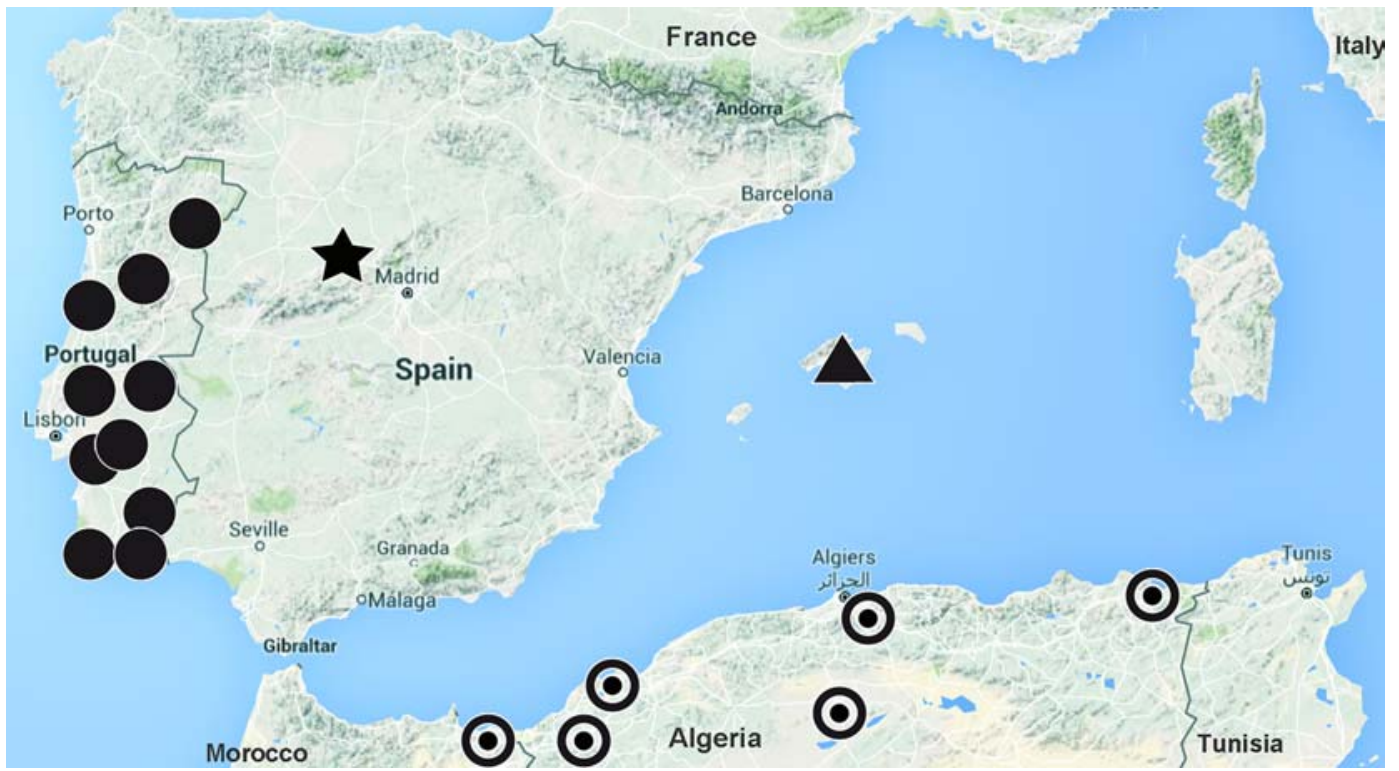

Fig. 30. Distribution records of Iberesia species (from Decae, 2005; Decae, Cardoso, 2006; Decae et al., 2007 and own data): solid circles - I. machadoi, asterick - I. castillana, triangle - I. brauni, dotted circles - I. barbara.

Рис. 30. Распространение видов рода Iberesia (по Decae, 2005, Decae, Cardoso, 2006; Decae et al., 2007 и собственным данным): сплошные кружки - I. machadoi, звездочка - I. castillana, треугольник - I. brauni, кружки с точкой в центре - I. barbara.

ters from the types of Mygale barbara and these two names considered here synonymous.

ACKNOWLEDGEMENTS. I use this possibility to thank Christine Rollard and Elise-Anne LeGuin (Paris, France) for the material kindly lent to me for examination, and Naomi Paz (Tel Aviv, Israel) for editing English of the final draft. The study was enabled with the financial help generously providing by the Ministry of Absorption, Israel.

\section{References}

Decae A.E. 2005. Trapdoor spiders of the genus Nemesia Audouin, 1826 on Majorca and Ibiza: taxonomy, distribution and behaviour (Araneae, Mygalomorphae, Nemesiidae) // Bulletin of the British Arachnological Society. Vol.13. P.145-168.

Decae A., Cardoso P. 2006. Iberesia, a new genus of trapdoor spiders (Araneae, Nemesiidae) from Portugal \& Spain // Revista Ibérica de Aracnología. Vol.12. P.3-11.
Decae A., Cardoso P., Selden P. 2007. Taxonomic review of the Portuguese Nemesiidae (Araneae, Mygalomorphae) // Revista Ibérica de Aracnología. Vol.14. P.1-18.

Lucas H. 1846. Histoire naturelle des animaux articulesb // Exploration scientifique de l'Algérie pendant les années 1840, 1841, 1842 publiée par ordre du Gouvernement et avec le concours d'une commission académique. Paris, Sciences physiques, Zoologie. T.1. P.89-271.

Simon E. 1892. Histoire naturelle des araignées. Paris. T.1. P.1256.

Simon E. 1911. Araneae // Jeannel R., de Peyerimhof P. (eds.). Récoltes entomologiques dans les Beni-Snassen (Maroc orientale) // Annales de la Société Entomologique de France. T.80. P.414-419.

World Spider Catalog. 2016. World Spider Catalog. Natural History Museum Bern, online at http://wsc.nmbe.ch, version 17.0, accessed on 15.01.2016.

Responsible editor Yu.M. Marusik 